\title{
Mediation of macronutrients and carbon by post- disturbance shelf sea sediment communities
}

\author{
Rachel Hale $\mathbb{D}$ - Jasmin A. Godbold • Marija Sciberras • Jessica Dwight • \\ Christina Wood · Jan G. Hiddink • Martin Solan
}

Received: 31 October 2016/ Accepted: 7 June 2017/Published online: 12 June 2017

(C) The Author(s) 2017. This article is an open access publication

\begin{abstract}
Benthic communities play a major role in organic matter remineralisation and the mediation of many aspects of shelf sea biogeochemistry. Few studies have considered how changes in community structure associated with different levels of physical disturbance affect sediment macronutrients and carbon following the cessation of disturbance. Here, we investigate how faunal activity (sediment particle reworking and bioirrigation) in communities that have survived contrasting levels of bottom fishing affect sediment organic carbon content and macronutrient concentrations $\left(\left[\mathrm{NH}_{4}-\mathrm{N}\right], \quad\left[\mathrm{NO}_{2}-\mathrm{N}\right]\right.$,
\end{abstract}

Electronic supplementary material The online version of this article (doi:10.1007/s10533-017-0350-9) contains supplementary material, which is available to authorized users.

Responsible Editor: Leila J. Hamdan.

R. Hale $(\bowtie) \cdot$ J. A. Godbold · J. Dwight .

C. Wood · M. Solan

School of Ocean and Earth Science, National

Oceanography Centre Southampton, University of

Southampton Waterfront Campus, European Way,

Southampton SO14 3ZH, UK

e-mail: r.hale@soton.ac.uk

\section{J. A. Godbold}

Biological Sciences,Faculty of Natural and Environmental Sciences, University of Southampton, Highfield Campus,

Life Sciences Building 85, Southampton SO17 1BJ, UK

M. Sciberras · J. G. Hiddink

School of Ocean Sciences, Bangor University, Menai

Bridge, Bangor LL59 5AB, UK
$\left.\left[\mathrm{NO}_{3}-\mathrm{N}\right],\left[\mathrm{PO}_{4}-\mathrm{P}\right],\left[\mathrm{SiO}_{4}-\mathrm{Si}\right]\right)$. We find that organic carbon content and $\left[\mathrm{NO}_{3}-\mathrm{N}\right]$ decline in cohesive sediment communities that have experienced an increased frequency of fishing, whilst $\left[\mathrm{NH}_{4}-\mathrm{N}\right],\left[\mathrm{NO}_{2}-\mathrm{N}\right],\left[\mathrm{PO}_{4}-\mathrm{P}\right]$ and $\left[\mathrm{SiO}_{4}-\mathrm{Si}\right]$ are not affected. $\left[\mathrm{NH}_{4}-\mathrm{N}\right]$ increases in noncohesive sediments that have experienced a higher frequency of fishing. Further analyses reveal that the way communities are restructured by physical disturbance differs between sediment type and with fishing frequency, but that changes in community structure do little to affect bioturbation and associated levels of organic carbon and nutrient concentrations. Our results suggest that in the presence of physical disturbance, irrespective of sediment type, the mediation of macronutrient and carbon cycling increasingly reflects the decoupling of organism-sediment relations. Indeed, it is the traits of the species that reside at the sediment-water interface, or that occupy deeper parts of the sediment profile, that are disproportionately expressed post-disturbance, that are most important for sustaining biogeochemical functioning.

Keywords Bioturbation - Biodiversity $\cdot$ Ecosystem function · Nitrogen · Biogeochemical cycles ·

Recovery

\section{Introduction}

Shelf seas are an important global resource that provide many benefits and ecosystem services to people, including nutrient cycling, carbon storage and 
food security (Worm et al. 2006), but human activity has led to degradation of many benthic habitats (Halpern et al. 2008). In particular, bottom fishingthe use of towed nets and dredges - causes surface and sub-surface physical disturbance that results in a range of morphological and biogeochemical changes in continental shelf and slope systems (Kaiser et al. 2000; Puig et al. 2012; Sciberras et al. 2016) depending on fishing type and frequency (Oberle et al. 2016), including sub-lethal injury or mortality of benthic invertebrates and the destruction of specific biogenic habitats (Kaiser et al. 2006; Cook et al. 2013). Bottom fishing practices may remove surficial sediments and mix organic matter into subsurface sediment layers where they can become buried (Duplisea et al. 2001; Warnken et al. 2003; O'Neill and Summerbell 2011). If burial of surficial sediments is below the oxic zone, organic matter is lost before aerobic remineralisation can take place (Mayer et al. 1991; Pilskaln et al. 1998) leading to increased anaerobic remineralisation through sulphate reduction (Duplisea et al. 2001; Trimmer et al. 2005). In addition, resuspension of sediments when fishing gears contact the sea bed increase both overlying water turbidity (Bradshaw et al. 2000; O'Neill and Summerbell 2011; O'Neill and Summerbell 2016; Martin et al. 2014) and suspended particulate organic matter concentration, which can modify phytoplankton production in shallow shelf seas (Riemann and Hoffmann 1991; Pilskaln et al. 1998; Palanques et al. 2001) and, subsequently, the remineralization of particulate organic matter to dissolved inorganic carbon, nitrogen and phosphorous. Associated changes in grain size distribution, increased sediment sorting and alterations to porosity (Trimmer et al. 2005) can disrupt nitrification and denitrification processes (Rysgaard et al. 1994) through changes in oxygen penetration (Warnken et al. 2003), which, in turn, may also affect faunal and microbial activity (Sciberras et al. in review). Over extended periods of time these physical and biogeochemical changes reduce habitat complexity (Kaiser et al. 2002) and alter community structure by reconfiguring species and functional trait dominance (Kaiser et al. 2006; Pusceddu et al. 2014; Sciberras et al. 2016), causing a shift from sessile emergent species with high biomass to smaller bodied infaunal species (Kaiser et al. 2000). Importantly, such selective forcing may skew trophic structure (Duffy 2003; Wohlgemuth et al. 2016) and lead to the loss of species interactions that influence nutrient generation and dynamics (Gilbertson et al. 2012); the active redistribution of particles and fluids by infaunal invertebrates, for example, directly contributes to the spatial and temporal heterogeneity of oxic and anoxic zones (Bertics and Ziebis 2009), the availability of organic matter (Levin et al. 1997), and the distribution of metabolic electron acceptors (Aller 1982; Fanjul et al. 2007) that are important in controlling microbial process rates and benthic-pelagic coupling linked to primary productivity (Lohrer et al. 2004).

Whilst the susceptibility of benthic communities and habitat integrity to perturbation associated with bottom fishing activity has long been established (Thrush and Dayton 2002; Jones 1992), evaluations of the longer term effects of restructured post-disturbance communities inhabiting altered sedimentary conditions on biogeochemical processes have been less prominent (Lambert et al. 2014). Cohesive shelf sediments have been considered to be particularly important areas for biogeochemical activity owing to the presence of elevated concentrations of organic matter and living biomass, contributing an estimated $44 \%$ of global denitrification and $>40 \%$ of total organic matter burial (Muller-Karger et al. 2005; Seitzinger et al. 2006; Middleburg and Levin 2009). However, non-cohesive sediments also play a major role in the turnover of particulate organic matter, despite comparatively lower levels of living biomass, because of the influence of advective processes (Rao et al. 2007, 2008). These mechanistic differences mean that in cohesive sediments the remineralisation of organic carbon and generation of macronutrients is largely driven by the reduction of solutes, such as nitrate and sulphate, whilst in non-cohesive sediments remineralisation processes reflect the extent of advective porewater flows (Rocha 2008). However, sediment or habitat type can be a poor predictor of biogeochemical performance (Dernie et al. 2003) because the active redistribution of particles and fluids by infaunal macro-invertebrates disproportionately influences benthic fluxes and total benthic metabolism (Banta et al. 1999; Mermillod-Blondin et al. 2004). Hence, the level of biogeochemical performance that is realised will depend, at least in part, on the structure and composition of the post-disturbance surviving community (Solan et al. 2004a; Thomsen et al. 2017; Wohlgemuth et al. 2017). Here, we investigate whether post-disturbance changes in epifaunal and 
infaunal assemblage structure result in associated changes in organic carbon and nutrient cycling along gradients of chronic fishing activity in fishing grounds that contrast in sediment type. Our a priori assumption was that benthic macrofaunal communities would be restructured by chronic physical disturbance and that the adjusted post-disturbance community would persist long after the perturbation event (van Colen et al. 2012). Consequently, the relative role of these surviving communities in moderating organic carbon and macronutrient dynamics will be context specific and relate to the introduction, removal or rebalancing of traits that directly influence the processes that govern remineralisation, advection, resuspension and burial within environmental context (Godbold and Solan 2009).

\section{Materials and methods}

To quantify the effects of chronic physical disturbance on macrofaunal community bioturbation (particle reworking, ventilation and bioirrigation), sediment organic carbon content and macronutrients, we focussed our study within the context of two important commercial fisheries located in the Irish Sea: (1) Norwegian Lobster (Nephrops norvegicus) grounds located in areas of cohesive (muddy) sediment that are fished using otter trawl nets with bobbin, roller and chain ground gear (sub-surface level impacts $\leq 35 \mathrm{~cm}$; Eigaard et al. 2015) and, (2) Scallop (Pecten maximus and Aequipecten opercularis) fishing grounds located in areas with non-cohesive (sandy) sediment that are fished using otter trawl nets and dredges with chains and a toothed beam (sub-surface level impacts $\leq 15 \mathrm{~cm}$; Eigaard et al. 2015). Following Sciberras et al. (2016), we categorised fishing activity in each area by computing the accumulated swept areas within a year from UK registered vessels ( $>15 \mathrm{~m}$ long) that use bottom-contact fishing gear over a 3 year period (sandy area: January 2009-December 2011, muddy area: January 2010-December 2012) to calculate the total seabed area swept $\left(\mathrm{km}^{2}\right)$ by a fishing gear per annum. Specifically, we focussed on six locations that contrast in fishing regime (Table 1; Fig. 1): three in cohesive sediment (Supplementary Table S1, mean grain size $<63 \mu \mathrm{m}$, Supplementary Figure S1, location: off the coast of Cumbria, England, disturbance intensities-low: 3.8 times annum ${ }^{-1}$, medium: 5.9 times annum ${ }^{-1}$, high: 8.4 times annum ${ }^{-1}$, where disturbance refers to the frequency of bottom trawling or dredging of an area per year, otter trawled for Nephrops norvegicus and gadoid fish year round; Hinz et al. 2009); and three in non-cohesive sediment (Supplementary Table S2, mean grain size 63-500 $\mu \mathrm{m}$, Supplementary Figure S2, location: off the east coast of the Isle of Man, fishing intensitieslow: 0.25 times annum $^{-1}$, medium: 0.51 times annum $^{-1}$, high: 1.63 times annum ${ }^{-1}$, dredged for Pecten maximus May to November and otter trawled for Aequipecten opercularis June to October; Murray et al. 2010; Dignan et al. 2014). Variation in habitat characteristics were minimised to ensure that any observed differences reflected disturbance associated changes in species composition rather than environmental variability (Table 1 ).

At each site, five replicate intact sediment subsamples (LWH: $20 \times 20 \times 12 \mathrm{~cm}$ ) were taken from $0.08 \mathrm{~m}^{2}$ NIOZ (Netherlands Institute for Sea Research, Texel) sediment cores collected from the RV Prince Madog (cruise: 22-28 June 2016), transferred to square transparent acrylic aquaria (LWH: $20 \times 20 \times 34 \mathrm{~cm})$ and overlaid by $\sim 20 \mathrm{~cm}(8 \mathrm{~L})$ of ambient seawater (salinity 33). Sediment surface scrapes were taken to determine sediment particle size (Malvern Mastersizer 2000, Malvern Instruments; Supplementary Figures S1 and S2) and percentage organic carbon content (loss on ignition, $375^{\circ} \mathrm{C}, 1 \mathrm{~h}$, Pansu and Gautheyrou 2006; org-C). Overlying seawater was replaced after $24 \mathrm{~h}$ to remove excess nutrients associated with assembly (Hale et al. 2014). Aquaria were maintained at ambient bottom temperature (Irish Sea, June 2016), $14{ }^{\circ} \mathrm{C}$, in the dark and continually aerated at the School of Ocean Sciences, Bangor University for 7 days.

Faunal mediated sediment particle reworking was estimated non-invasively using fluorescent sediment profile imaging (f-SPI, following Solan et al. 2004b; Canon 400D, $10 \mathrm{~s}$ exposure, aperture f5.6, ISO 400, $3888 \times 2592$ pixels, effective resolution $\left.39 \times 39 \mu \mathrm{m} \mathrm{pixel}^{-1}\right)$. Redistribution of fluorescent

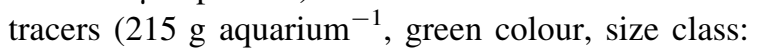
$<125 \mu \mathrm{m}$, mean particle size $\sim 80 \mu \mathrm{m}$; Brian Clegg Ltd., UK) was determined from stitched composite images (four sides aquarium ${ }^{-1}$; RGB colour, JPEG compression) obtained under UV light illumination (Schiffers et al. 2011) after 6 days. The maximum vertical deviation of the sediment-water interface 
Table 1 Representative site information after Sciberras et al. (2016)

\begin{tabular}{lllllll}
\hline Station & Sediment & Depth $(\mathrm{m})$ & Tide stress $\left(\mathrm{N} \mathrm{m}^{-2}\right)$ & Wave stress $\left(\mathrm{N} \mathrm{m}^{-2}\right)$ & Fishing frequency $\left(\right.$ annum $\left.^{-1}\right)$ & Fishery type \\
\hline M1 & Mud & 26.0 & 0.17 & 0.69 & 3.8 & Lobster \\
M2 & Mud & 28.0 & 0.16 & 0.52 & 5.9 & Lobster \\
M3 & Mud & 28.5 & 0.22 & 0.68 & 8.4 & Lobster \\
S1 & Sand & 19.8 & 0.17 & 1.00 & 0.25 & Scallop \\
S2 & Sand & 18.3 & 0.17 & 1.14 & 0.51 & Scallop \\
S3 & Sand & 18.8 & 0.11 & 0.73 & 1.63 & Scallop \\
\hline
\end{tabular}

See Supplementary Figures S1 and S2 for sediment particle size detail and Supplementary Tables 1 and 2 for station location coordinates

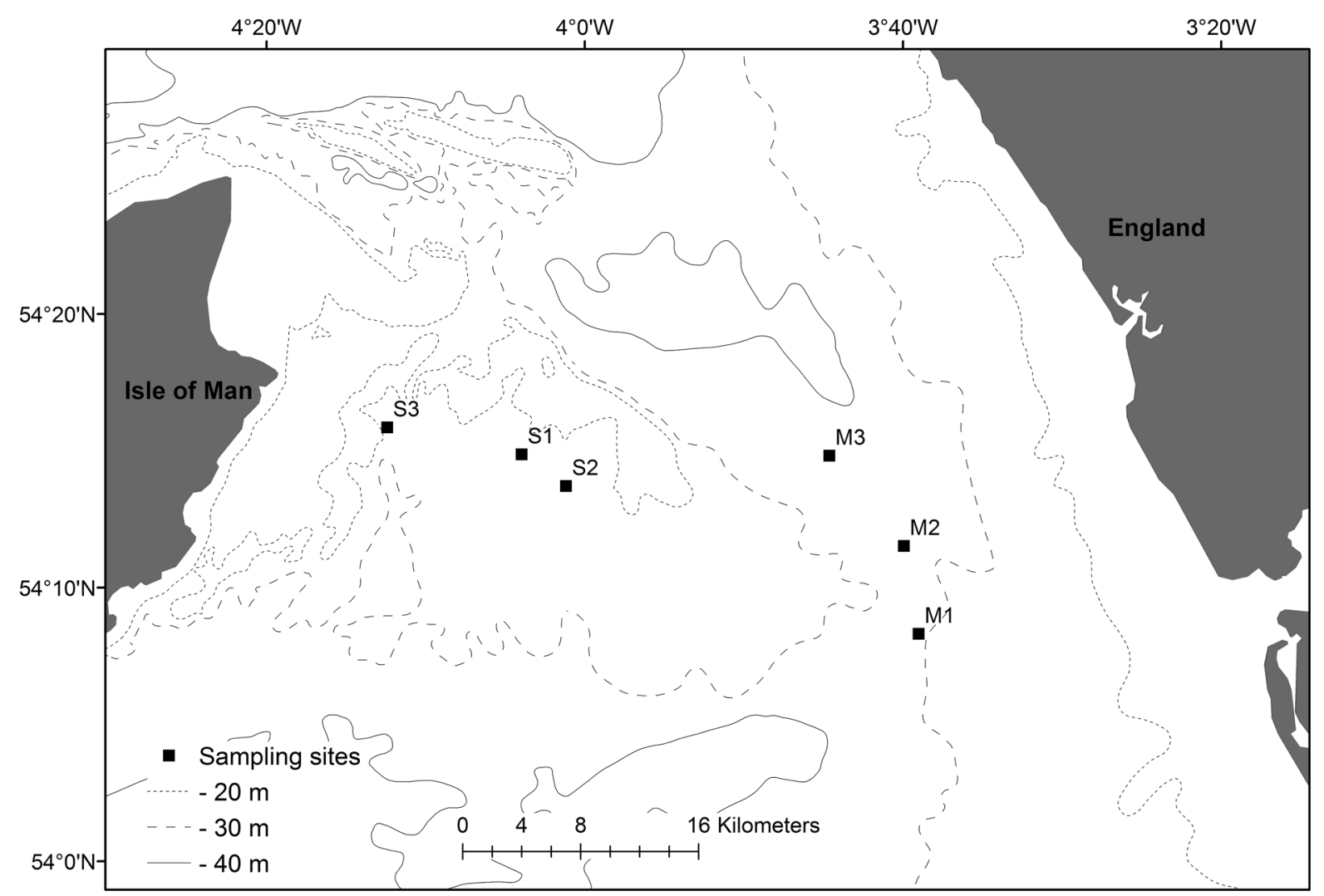

Fig. 1 The location of study sites in the Irish Sea. Site characteristics are listed in Table 1 and station co-ordinates are listed in Supplementary Tables S1-S2. Sediment type is

(upper-lower limit $=$ surface boundary roughness, SBR) provided an indication of surficial activity. Following Hale et al. (2014), the mean $\left({ }^{\mathrm{f}-\mathrm{SPI}} \mathrm{L}_{\text {mean }}\right.$, time dependent indication of mixing), median ( ${ }^{\mathrm{f}-\mathrm{SPI}} \mathrm{L}_{\text {med }}$, short-term depth of mixing), and maximum ( ${ }^{\mathrm{f}-\mathrm{SPI}} \mathrm{L}_{\mathrm{max}}$, full extent of vertical mixing over the longterm) depths of particle redistribution were calculated denoted as: $M$ cohesive (muddy) sediments; or $S$ non-cohesive (sandy) sediments. The frequency of fishing is: 1 low; 2 medium; or 3 high

using a custom-made semi-automated macro that runs within FIJI (Schindelin et al. 2012; ImageJ, Version $1.47 \mathrm{v})$.

Absolute concentrations of ammonium $\left(\left[\mathrm{NH}_{4}-\mathrm{N}\right]\right)$, nitrite $\left(\left[\mathrm{NO}_{2}-\mathrm{N}\right]\right)$, nitrate $\left(\left[\mathrm{NO}_{3}-\mathrm{N}\right]\right)$, phosphate $\left(\left[\mathrm{PO}_{4}-\mathrm{P}\right]\right)$ and silicate $\left(\left[\mathrm{SiO}_{4}-\mathrm{Si}\right]\right)$ were quantified (Technicon segmented flow colorimetric auto- 
analyser) in seawater samples $(30 \mathrm{~mL}, 0.45 \mu \mathrm{m}$ filtered) taken on day 5. Bioirrigation was quantified (Tecator flow injection auto-analyser, FIA Star 5010 series) from absolute changes (over $6 \mathrm{~h}$ ) in the concentration of the inert tracer sodium bromide $\left(\Delta\left[\mathrm{Br}^{-}\right], \mathrm{mg} \mathrm{L}^{-1}\right.$; applied concentration: $8.231 \mathrm{~g}$ sodium bromide, equivalent to $10 \mathrm{mM}$ concentration; negative values indicate increased bioirrigation activity; Forster et al. 1999).

The sediment and associated macrofauna community (retained on $500 \mu \mathrm{m}$ sieve) in each aquarium were fixed in a $10 \%$ formalin (4\% formaldehyde) solution buffered with seawater (salinity, 33) on Day 7. Species were identified to the lowest possible taxon $(94 \%$ to species, excluding Nematoda, which made up $36 \%$ of faunal abundance) and enumerated. For the estimation of biomass, fauna were blotted dry on an absorbent paper to remove excess liquid prior to wet weighing. All bivalves and gastropods were weighed within their shell. All tube dwelling worms (e.g. Lanice conchilega, Owenia fusiformis) were removed from their tubes prior to weighing.

As the two fisheries under study use different gears and operate in distinct habitat types with taxonomically different communities (Supplementary Figure S3), it was not possible to distinguish the effects of sediment type from the effects of fishing frequency within a single statistical analysis. Instead, single factor linear models were generated to examine the effect of bottom fishing disturbance for the dependent variables (SBR, ${ }^{\mathrm{f}-\mathrm{SPI}} \mathrm{L}_{\text {mean }},{ }^{\mathrm{f}-\mathrm{SPI}} \mathrm{L}_{\text {med }},{ }^{\mathrm{f}-\mathrm{SPI}} \mathrm{L}_{\text {max }}, \Delta\left[\mathrm{Br}^{-}\right]$, org-C, $\left[\mathrm{NH}_{4}-\right.$ $\mathrm{N}],\left[\mathrm{NO}_{2}-\mathrm{N}\right],\left[\mathrm{NO}_{3}-\mathrm{N}\right],\left[\mathrm{PO}_{4}-\mathrm{P}\right],\left[\mathrm{SiO}_{4}-\mathrm{Si}\right]$ ) within each fishery. Where variance was heterogeneous, a generalised least squares fitting approach (Pinheiro and Bates 2000; West et al. 2007) was applied (library: nlme; Pinheiro et al. 2016). In the non-cohesive sediments, we removed one outlier (associated with presence of a single individual of the Brachyuran crab Goneplax rhomboides) from the analysis $\left(\left[\mathrm{NH}_{4}-\mathrm{N}\right]\right.$ : Cooks distance 0.93, $\left[\mathrm{NO}_{2}-\mathrm{N}\right]$ : Cooks distance 0.98, and $\left[\mathrm{NO}_{3}-\mathrm{N}\right]$ : Cooks distance 0.75). These analyses were conducted in R (R Core Team 2016; Version 3.3.1) and supplementary model (SM) information (the initial linear regression model, the minimal adequate model with GLS estimation, and a summary of the coefficient table) is included in the Supplementary Material. Community differences associated with the disturbance regime within each sediment type were determined graphically using non-metric multidimensional scaling (MDS) and quantified using Analysis of Similarities (ANOSIM) randomisation test based on abundance and biomass. The MDS procedure is based upon an iterative algorithm that repeatedly refines the distance between points in n-dimensional space until they fall into agreement with the similarity pattern for the same data. The distance in n-dimensional space that sample points deviate from the derived model forms a measure of the goodness of fit ("stress", where a perfect representation has zero stress) of the resulting MDS plot (Clarke and Ainsworth 1993). MDS ordination representation stress values are indicated. The value of stress increases with reducing dimensionality of the ordination and lower values minimize misrepresentation (acceptable when $<0.30$ ). The relative contribution of individual species to the community was identified by calculating similarity percentages SIMPER (PRIMER+, Version 7). All data are available from the British Oceanographic Data Centre (Hale et al. 2017).

\section{Results}

Cohesive sediments

The number of species found at the cohesive sediment sites ranged from 5 to 17 . Total species abundance and biomass ranged from 249 to 1020 individuals $\mathrm{m}^{-2}$ and 0.14 to $16.99 \mathrm{~g} \mathrm{~m}^{-2}$ respectively. Sites with different disturbance regimes did not differ in macrofaunal community abundance (nMDS, Fig. 2a; ANOSIM, p =0.458), but did differ in macrofaunal community biomass (nMDS, Fig. 2b; ANOSIM, $\mathrm{p}=0.013$, Supplementary Table S3); the composition and total biomass of the species found at the site with a history of medium disturbance frequency was different from that found at the site with a history of low disturbance frequency (Mean biomass $\pm \mathrm{SD}, \mathrm{n}=5$ : Site $_{\text {med }}, \quad 4.08 \pm$

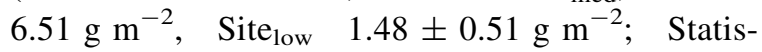
tic $=0.388, p=0.008)$. Compositional differences between sites were largely associated with increased polychaete biomass (in particular, Nephtys incisa and Notomastus laticerus) at the site with a history of low disturbance frequency, the presence of a single individual of the decapod Goneplax rhomboides $(1.29 \mathrm{~g})$ at the site with a history of medium disturbance frequency (Supplementary Table S3). 


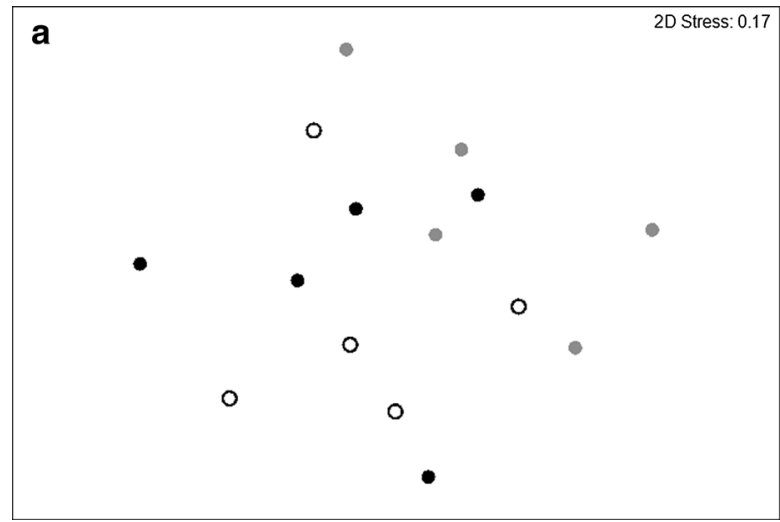

Fig. 2 Non-metric two dimensional MDS configurations of log transformed Bray-Curtis similarity matrices of invertebrate $\mathbf{a}$ abundance, and $\mathbf{b}$ biomass for communities in cohesive sediment communities that have experienced contrasting levels

The redistribution of sediment particles and fluids by the resident infauna were not affected by changes in the composition or structure of the community in cohesive sediment communities (SM S1-5). Surface boundary roughness (SBR) ranged from 0.84 to $6.25 \mathrm{~cm}$, whilst the maximum vertical extent of mixing relative to the sediment-water interface $\left({ }^{\mathrm{f}-\mathrm{SPI}} \mathrm{L}_{\text {max }}\right)$ ranged from 1.05 to $8.26 \mathrm{~cm}\left({ }^{\mathrm{f}-\mathrm{SPI}} \mathrm{L}_{\text {mean }}\right.$, 0.44 to $0.99 \mathrm{~cm} ;{ }^{\text {f-SPI }} \mathrm{L}_{\text {med }}, 0.24$ to $0.71 \mathrm{~cm}$ ) across all cohesive sediment locations.

In communities with a history of a low frequency of fishing disturbance, mean sediment carbon content (org-C, $\pm \mathrm{SE} ; \mathrm{n}=5 ; 2.00 \pm 0.16$ ) was greater than in the sediments that experienced either a medium (coefficient $\pm \mathrm{SE}=0.43 \pm 0.16, \mathrm{t}=-2.64, \quad \mathrm{p}=$ $0.022)$ or high frequency of fishing disturbance (coefficient $\pm \mathrm{SE}=0.41 \pm 0.16, \quad \mathrm{t}=-2.49, \quad \mathrm{p}=$ 0.028 , Fig. 3a; SM S6). With the exception of $\left[\mathrm{NO}_{3}-\right.$ $\mathrm{N}$ ] we found no evidence that overlying seawater nutrient concentrations $\left(\left[\mathrm{NH}_{4}-\mathrm{N}\right]\right.$ range 5.11$20.91 \mu \mathrm{M}, \mathrm{SM} \mathrm{S} 7 ;\left[\mathrm{NO}_{2}-\mathrm{N}\right]$ range $0.17-0.39 \mu \mathrm{M}$, SM S8; $\left[\mathrm{PO}_{4}-\mathrm{P}\right]$ range $0.17-0.91 \mu \mathrm{M}, \mathrm{SM} \mathrm{S} 10$; and $\left[\mathrm{SiO}_{4}-\mathrm{Si}\right]$ range $13.77-30.90 \mu \mathrm{M}$, SM S11) were affected by any changes in the composition or structure of the community. Sediments with a history of lower and medium disturbance frequency had higher mean overlying $\left[\mathrm{NO}_{3}-\mathrm{N}\right]( \pm \mathrm{SE} ; \mathrm{n}=5 ; 3.05 \pm$ 0.33 and $3.05 \pm 0.24 \mu \mathrm{M}$, respectively) than those with a history of higher frequency disturbance (coefficient \pm SE: $-0.92 \pm 0.41, t=2.23, p=0.045$ and b

2D Stress: 0.08

(2)

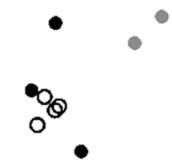

$\circ$

of bottom fishing frequency (open circle low, closed circle medium, and closed circle high). MDS dimensionality representation stress values are $\mathbf{a} 0.17$ and $\mathbf{b} 0.08$

$-0.9 \pm 0.41, \quad \mathrm{t}=2.22, \quad \mathrm{p}=0.046, \quad$ respectively; Fig. 3b, SM S9).

Non-cohesive sediments

The number of species at sites with non-cohesive sediments ranged from 4 to 15 . Species total abundance and biomass ranged from 87 to 1144 individuals $\mathrm{m}^{-2}$ and 0.12 to $406.79 \mathrm{~g} \mathrm{~m}^{-2}$ respectively. In non-cohesive sediments, community composition and abundance separated from one another with respect to disturbance frequency (nMDS, Fig. 4a; ANOSIM, $\mathrm{p}=0.001 ; \quad$ low:medium $\quad$ Statistic $=0.392, \quad \mathrm{p}=$ 0.008 , low:high Statistic $=0.36, p=0.032$, medium:high Statistic $=0.52, \mathrm{p}=0.008$ ). This delineation was largely due to a comparatively higher representation of polychaetes (Poecilochaetus serpens, Magelona minuta, and Sthenelais limicola) in communities with a history of low frequency disturbance; the polychaete Lagis koreni in communities with a history of low and medium frequency disturbance; Nematoda in communities with a history of medium frequency disturbance; and the polychaete Ophelina acuminata in communities with a history of high frequency disturbance (Supplementary Table S4). Similarly, the composition and total biomass of species within communities that experienced a history of low and medium frequency disturbance differed from those with a history of high frequency disturbance (nMDS, Fig. 4b; ANOSIM, $\mathrm{p}=0.008$; low:high 


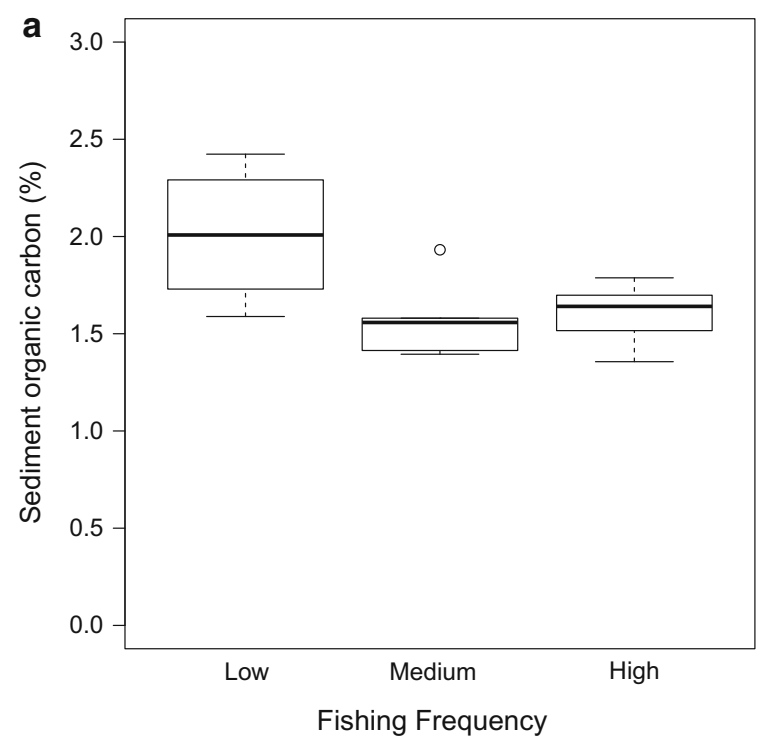

Fig. 3 The effect of contrasting levels of bottom fishing frequency on a sediment organic carbon content $(\%)$ and b overlying $\left[\mathrm{NO}_{3}-\mathrm{N}\right](\mu \mathrm{M})$ in cohesive sediment communities.

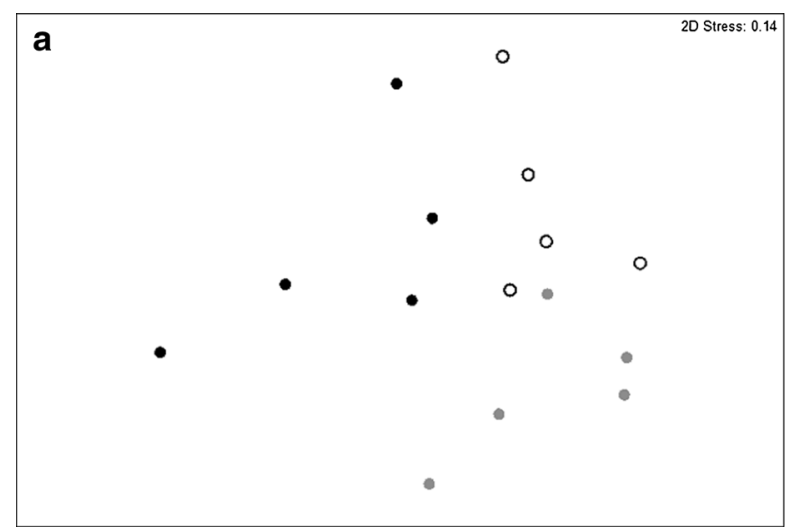

Fig. 4 Non-metric two dimensional MDS configurations of $\log$ transformed Bray-Curtis similarity matrices of invertebrate $\mathbf{a}$ abundance, and $\mathbf{b}$ biomass for communities in non-cohesive sediment communities that have experienced contrasting levels

Statistic $=0.312, \mathrm{p}=0.008$, medium:high Statistic $=0.32, p=0.024)$. This delineation relates to the presence of a razor clam, Ensis ensis (25.81 g) within the communities that have experienced medium frequency disturbance, a large urchin Echinocardium cordatum (13.46 g) and bivalve Garifervensis (3.21 g) within the communities that have experienced high frequency disturbance, an increase in the biomass of the polychaete Lagis koreni from low to medium frequency disturbance, and the absence of several

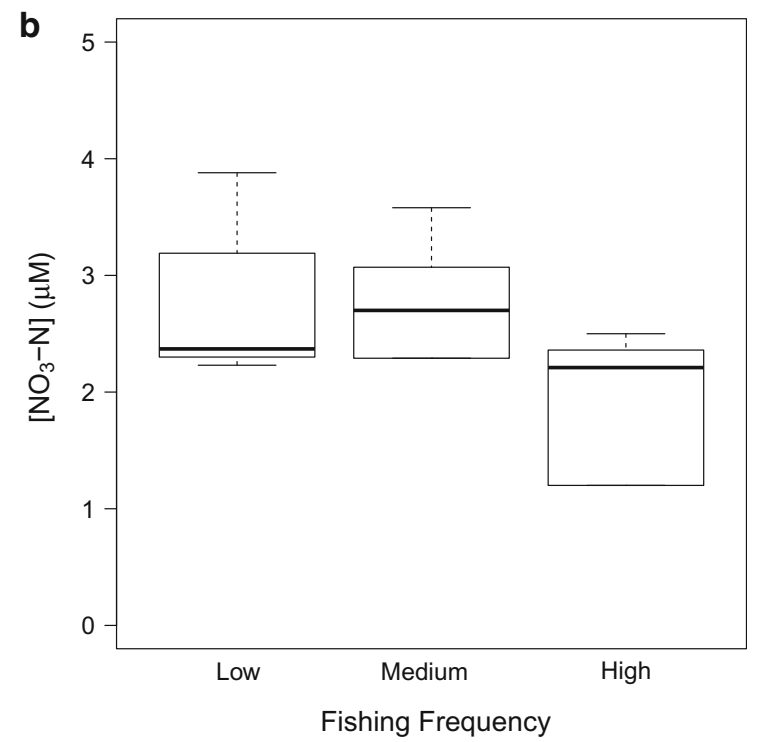

In each case, the median is indicated at the midpoint, the upper and lower quartiles are indicated by the hinges, lines represent the spread and open circles indicate outliers

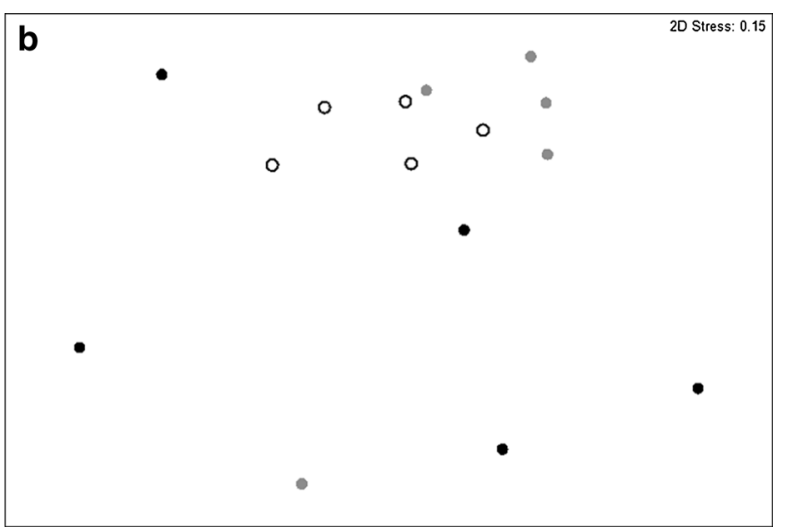

of bottom fishing frequency (open circle low, closed circle medium, and closed circle high). MDS dimensionality representation stress values are $\mathbf{a} 0.17$ and $\mathbf{b} 0.08$

species in communities that have experienced low or medium frequency disturbance (Supplementary Table S5).

The mean ${ }^{\mathrm{f}-\mathrm{SPI}} \mathrm{L}_{\text {mean }}$, range $0.67-1.25 \mathrm{~cm} ; \mathrm{SM}$ $\mathrm{S} 13)$ and median $\left({ }^{\mathrm{f}-\mathrm{SPI}} \mathrm{L}_{\text {med }}\right.$, range $0.64-1.10 \mathrm{~cm} ; \mathrm{SM}$ S14) depth of sediment reworking were unaffected by the composition or structure of the community. In contrast, mean $( \pm \mathrm{SE} ; \mathrm{n}=5)$ surface boundary roughness (SBR; SM S12; Fig. 5a) was higher in communities that have experienced medium frequency 
disturbance $(2.75 \pm 0.31)$ relative to those that had experienced low frequency disturbance (coefficient $\pm \mathrm{SE}=-0.96 \pm 0.4, \quad \mathrm{t}=2.19, \quad \mathrm{p}=0.048$ ) SBR was variable at the sites that had experienced a high frequency of disturbance, and did not differ from those observed at the low or medium frequency disturbance sites. Additionally, the mean $( \pm \mathrm{SE}$; $\mathrm{n}=5$ ) maximum depth of sediment reworking $\left({ }^{\mathrm{f}-\mathrm{SPI}} \mathrm{L}_{\max }\right.$; SM S15; Fig. $\left.5 b\right)$ in communities that have experienced high frequency disturbance $(4.64 \pm 0.50 \mathrm{~cm})$ was deeper than in those that had experienced low (coefficient \pm s.e. $=-2.65 \pm 0.63$, $\mathrm{t}=4.22, \quad \mathrm{p}=0.001$ ) or medium (coefficient $\pm \mathrm{SE}=-1.69 \pm 0.63, \mathrm{t}=2.70, \mathrm{p}=0.020$ ) frequency disturbance. Bioirrigation $\left(\Delta\left[\mathrm{Br}^{-}\right]\right)$did not change with disturbance history (SM S16).

Changes in the composition or structure of the community had no discernable effect on sediment carbon content (org-C; range, $0.23-0.51 \%$; SM S17) in non-cohesive sediments. For macronutrients, with the exception of $\left[\mathrm{NH}_{4}-\mathrm{N}\right]$, we found no evidence that overlying seawater nutrient concentrations $\left(\left[\mathrm{NO}_{2}-\mathrm{N}\right]\right.$, range 0.19-0.38 $\mu \mathrm{M}$, outlier $1.76 \mu \mathrm{M}$, SM S19; [ $\mathrm{NO}_{3}-$ $\mathrm{N}$ ], range 1.39-3.98 $\mu \mathrm{M}$, outlier $13.28 \mu \mathrm{M}$, SM S20; $\left[\mathrm{PO}_{4}-\mathrm{P}\right]$, range $0.35-2.84 \mu \mathrm{M}, \mathrm{SM} \mathrm{S} 21$; and $\left[\mathrm{SiO}_{4}-\mathrm{Si}\right]$, range $24.19-65.79 \mu \mathrm{M}$, SM S22) were affected by the

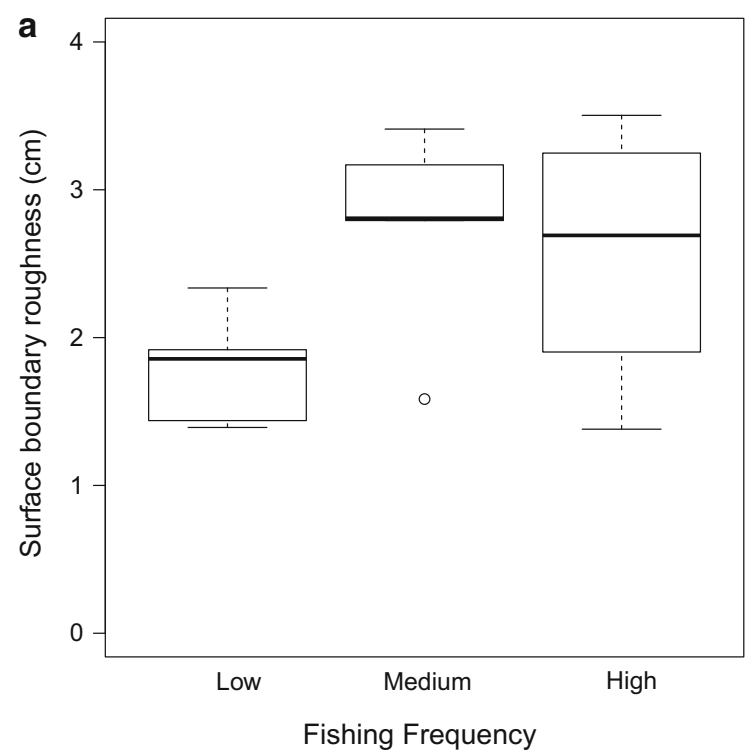

Fig. 5 The effect of contrasting levels of bottom fishing frequency on a surface boundar roughness $(\mathrm{cm})$ and $\mathbf{b}$ the maximum mixed depth of particle reworking $\left({ }^{\mathrm{f}-\mathrm{SPI}} \mathrm{L}_{\max }, \mathrm{cm}\right)$ in non-cohesive sediment communities. In each case, the median is disturbance history of the community. Sediments with a history of higher frequency disturbance had a larger mean $( \pm \mathrm{SE} ; \mathrm{n}=5)$ overlying $\left[\mathrm{NH}_{4}-\mathrm{N}\right](50.51 \pm$ $26.51 \mu \mathrm{M})$ than those with a history of low and medium frequency of disturbance (Fig. 6, SM S18; (coefficient $\pm \mathrm{SE}=-28.24 \pm 12.62, \mathrm{t}=2.24, \mathrm{p}=0.047$; coefficient $\pm \mathrm{SE}=-32.66 \pm 13.38, \mathrm{t}=2.44, \mathrm{p}=$ 0.033 respectively).

\section{Discussion}

Our study indicates a negative influence of chronic physical disturbance on the integrity of invertebrate communities, but reveals that the form and extent of restructuring is dependent on sediment type. In cohesive sediments, we find that there are few differences between sediment communities that have experienced different frequencies of fishing (as found in Pommer et al. 2016), but there are fundamental changes in species composition, abundance and biomass among post-fishing disturbance levels in non-cohesive sediments. Importantly, these alterations to infaunal biodiversity are not necessarily transformative in terms of biogeochemical functioning as theory might predict (Cardinale et al. 2012), rather

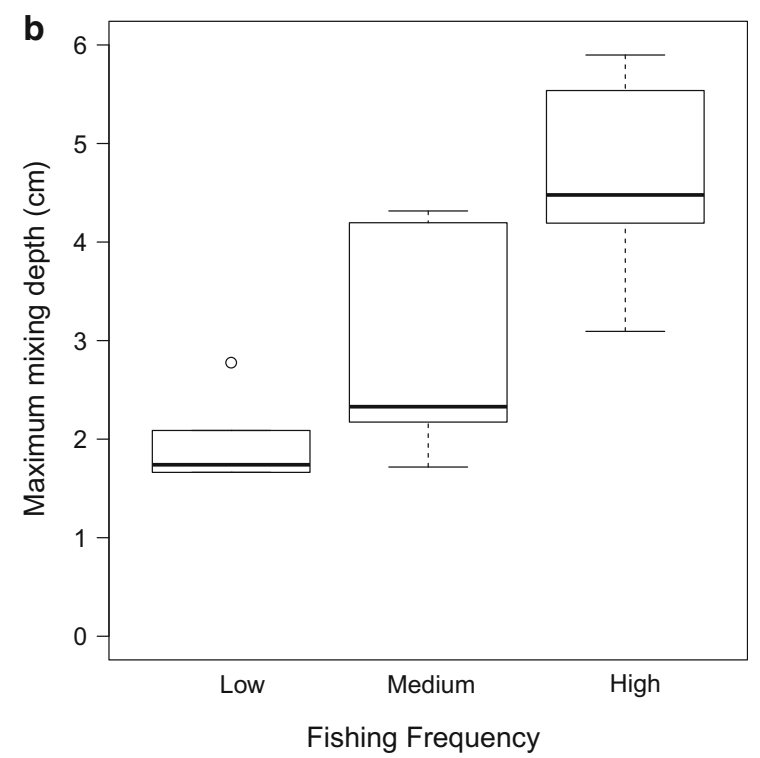

indicated at the midpoint, the upper and lower quartiles are indicated by the hinges, lines represent the spread and open circles indicate outliers 


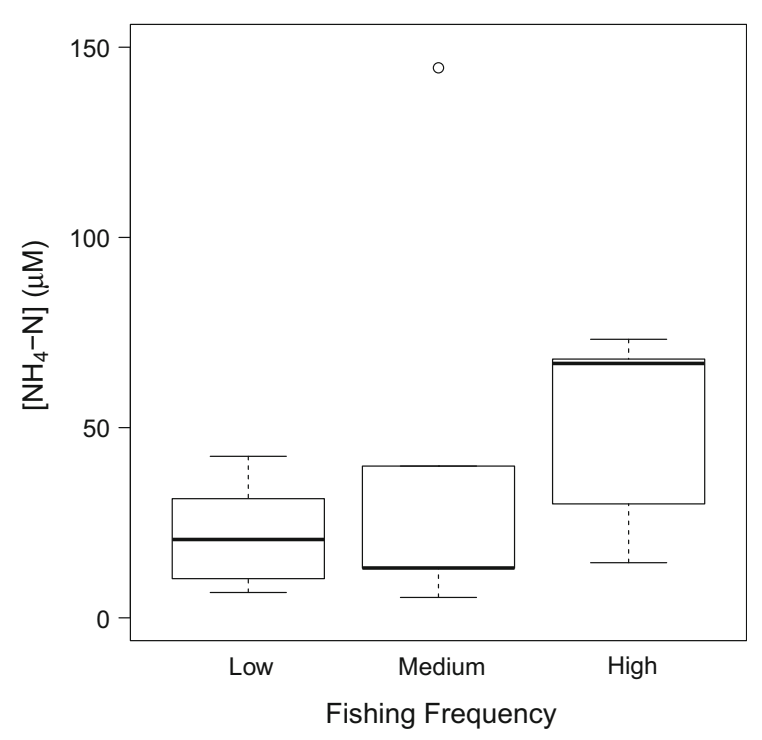

Fig. 6 The effect of contrasting levels of bottom fishing frequency on overlying $\left[\mathrm{NH}_{4}-\mathrm{N}\right](\mu \mathrm{M})$ in non-cohesive sediment communities. In each case, the median is indicated at the midpoint, the upper and lower quartiles are indicated by the hinges, lines represent the spread and open circles indicate outliers

there is little to differentiate the relative contribution of post-disturbance communities in moderating organic carbon and macronutrient dynamics (Wrede et al. 2017). Alterations in community biomass associated with fishing pressure, as observed here, are known to decrease the strength of interspecific interactions and minimise the effects of biodiversity on ecosystem processes (Caliman et al. 2012), yet the lowest species abundances documented here were not in communities that had experienced the greatest frequency of fishing. This apparently anomalous finding can be explained, however, because the areas under study likely represent a permanently disrupted state (Collie et al. 2000; Kaiser et al. 2000; Pommer et al. 2016), with recovery times measured in years (Kaiser et al. 2006). In such environments there tends to be a predominance of small species with opportunistic reproductive modes that are able to respond quickly post-disturbance and can reach high abundances, but these species are more likely to have a low bioturbation potential (Solan et al. 2004a; Queirós et al. 2013). As per capita effects on sediment-water nutrient fluxes are disproportionately greater for larger polychaetes (Bosch et al. 2015), there is less capacity for most of the resident infauna to influence biogeochemical processes. A similar effect is also true for non-cohesive sediments which, due to their inherent mobility, host a high proportion of opportunistic species (Collie et al. 2000), but these communities also harbour large deep-burrowing fauna (e.g. decapod crustaceans, spatangoid urchins) that can form extensive galleries (Lohrer et al. 2004) and disproportionately augment oxygen uptake (Volkenborn et al. 2012) and the flux of dissolved substances across the water-sediment interface (Osinga et al. 1995; Bird et al. 1999; D'Andrea and DeWitt 2009). The presence of these species, in particular the spatangoid Echinocardium cordatum, offers an explanation for the enhanced $\left[\mathrm{NH}_{4}-\mathrm{N}\right]$ observed in noncohesive sediment communities that have experienced a high frequency of fishing activity.

Based on our findings, a naïve hypothesis would be that the frequency of physical disturbance (here, bottom fishing) is less important for biogeochemical cycling in cohesive sediments than it is in noncohesive sediments, but in the absence of a comparable fully functional ecosystem such a conclusion is premature (Thrush and Dayton 2002). Indeed, even a low frequency of disturbance can cause significant changes to the biotic and abiotic components of the system (Kaiser et al. 2000) and it is possible that intensive fishing disturbance can cause a reduction of $\left[\mathrm{NO}_{3}-\mathrm{N}\right]$ that relates to over-mobilisation of sediment, increased microbial activity, and net loss of $\mathrm{N}$ from the sediments (Bertics et al. 2010, Laverock et al. 2011, Mayer et al. 1998). Whilst it is clear that non-cohesive sediment communities are vulnerable to changes in the frequency of fishing, even though the fishing pressure is relatively low, near-bed current flows and the permeability of the sediment profile mean that organic carbon cycling is already rapid (Rocha 2008), making it difficult to assess how nutrient sediment-water exchange is affected as communities are modified. Cohesive sediments by contrast, are dominated by diffusive processes, where the remineralisation of organic matter is largely driven by the reduction of solutes (Kitidis et al. 2017). The decreasing pattern in $\left[\mathrm{NO}_{3}-\mathrm{N}\right]$ with increasing $\left[\mathrm{NH}_{4}-\mathrm{N}\right]$ observed here suggests that macrofaunal bioturbation did stimulate microbial denitrification. We also observed an increase in $\left[\mathrm{NO}_{3}-\mathrm{N}\right]$ within communities that had experienced the lowest frequency of fishing. As archaeal and bacterial denitrifiers and anammox transcripts are known to increase in communities that 
have been subject to greater disturbance by bottom fishing (Sciberras et al. in review), it is tempting to speculate that increased bioturbation activity in less impacted (more diverse) communities leads to a decline in $\left[\mathrm{NO}_{3}-\mathrm{N}\right]$ by increasing oxygen availability and stimulating, nitrification, however we did not observe any notable differences in bioturbation or community structure across the range of sediment communities.

Overall, our results emphasise the importance of benthic community composition and structure for sustaining biogeochemical condition in both cohesive and non-cohesive sediments. Importantly, the form and extent of community restructuring depends on the susceptibility of individual species within the community, differs between sediment type and with the characteristics of physical forcing (here, frequency and type of fishing). Our data indicate that species traits become skewed towards opportunistic lifestyles that have minimal capacity for influencing the postdisturbance recovery of biogeochemical condition and, under these circumstances organism-sediment relations that underpin the mediation of macronutrient and carbon cycling can become decoupled. However, our data indicate that the difference in the numbers of opportunistic species between low and high fishing frequency is greater in non-cohesive sediments. Whilst fishing pressure and other anthropogenic activities are increasingly relevant to the protection of natural capital and the sustainable management of ecosystem services (Ormerod and Carleton 2016), our findings suggest that management should focus on the connectivity between multiple factors that contribute to biogeochemical performance (Pittman and Armitage 2016). In particular understanding when and under what circumstances organism-sediment relations become decoupled will be of value in determining the mechanistic link between forcing, the selective alteration of biotic communities and the observed levels of ecosystem functioning.

Acknowledgements All data are available from the British Oceanographic Data Centre (www.bodc.ac.uk). Hale et al. (2017). This work was conducted under Work Package 2 of the Shelf Sea Biogeochemistry Programme (SSB WP2, NE/ K001906/1 and NE/K001639/1, 2011-2017), jointly funded by the Natural Environment Research Council (NERC) and the Department for Environment, Food and Rural Affairs (Defra). The views expressed are those of the authors and do not necessarily represent those of NERC or Defra. We also acknowledge the use of data obtained under the EU FP7 BENTHIS
(Benthic Ecosystem Fisheries Impact Studies) Project (312088). We thank the crew of RV Prince Madog, Ashleigh Currie, Leigh Howarth, Steve Balestrini, and Marine Cendrier for technical assistance.

Open Access This article is distributed under the terms of the Creative Commons Attribution 4.0 International License (http:// creativecommons.org/licenses/by/4.0/), which permits unrestricted use, distribution, and reproduction in any medium, provided you give appropriate credit to the original author(s) and the source, provide a link to the Creative Commons license, and indicate if changes were made.

\section{References}

Aller RC (1982) The effects of macrobenthos on chemical properties of marine sediment and overlying water. In: Mc Call PL, Tevesz MJS (eds) Animal-sediment relationsthe biogenic alteration of sediments.Topics in geobiology, vol 2. Plenum Press, New York, pp 53-102

Banta GT, Holmer M, Jensen MH, Kristensen E (1999) Effects of two polychaete worms, Nereis diversicolor and Arenicola marina, on aerobic and anaerobic decomposition in a sandy marine sediment. Aquat Microb Ecol 19:189-204

Bertics VJ, Ziebis W (2009) Biodiversity of benthic microbial communities in bioturbated coastal sediments is controlled by geochemical microniches. ISME J 3(11):1269-1285

Bertics VJ, Sohm JA, Treude T, Chow C-ET, Capone DG, Fuhrman JA, Ziebis W (2010) Burrowing deeper into benthic nitrogen cycling: the impact of bioturbation on nitrogen fixation coupled to sulfate reduction. Mar Ecol Prog Ser 409:1-15

Bird FL, Ford PW, Hancock GJ (1999) Effect of burrowing macrobenthos on the flux of dissolved substances across the water-sediment interface. Mar Freshw Res 50:523-532

Bosch JA, Cornwell JC, Kemp WM (2015) Short-term effects of nereid polychaete size and density on sediment inorganic nitrogen cycling under varying oxygen conditions. Mar Ecol Prog Ser 524:155-169

Bradshaw C, Veale LO, Hill AS, Brand AR (2000) The effects of scallop dredging on gravely seabed communities. In: Kaiser MJ, De Groot SJ (eds) The effects of fishing on nontarget species and habitats. Gray Publishing, Tunbridge Wells

Caliman A, Carneiro LS, Leal JJF, Farjalla VF, Bozelli RL, Esteves FA (2012) Community biomass and bottom up multivariate nutrient complementarity mediate the effects of bioturbator diversity on pelagic production. PLoS ONE 7:e44925

Cardinale BJ, Duffy JE, Gonzalez A, Hooper DU, Perrings C, Venail P, Narwani A, Mace GM, Tilman D, Wardle DA, Kinzig AP, Daily GC, Loreau M, Grace JB, Larigauderie A, Srivastava DS, Naeem S (2012) Biodiversity loss and its impact on humanity. Nature 486:59-67

Clarke KR, Ainsworth M (1993) A method of linking multivariate community structure to environmental variables. Mar Ecol Prog Ser 92:205-219 
Collie JS, Hall SJ, Kaiser MJ, Poiner IR (2000) A quantitative analysis of fishing impacts on shelf-sea benthos. J Anim Ecol 69:785-798

Cook R, Fariñas-Franco JM, Gell FR, Holt RHF, Holt T, Lindenbaum C, Porter JS, Seed R, Skates LR, Stringell TB, Sanderson WG (2013) The substantial first impact of bottom fishing on rare biodiversity hotspots: a dilemma for evidence-based conservation. PLoS ONE 8:e69904

D'Andrea AF, DeWitt TH (2009) Geochemical ecosystem engineering by the mud shrimp Upogebia pugettensis (Crustacea: Thalassinidae) in Yaquina Bay, Oregon: density-dependent effects on organic matter remineralization and nutrient cycling. Limnol Oceanogr 54:1911-1932

Dernie KM, Kaiser MJ, Richardson EA, Warwick RM (2003) Recovery of soft sediment communities and habitats following physical disturbance. J Exp Mar Biol Ecol 285:415-434

Dignan SP, Bloor ISM, Murray LG, Kaiser MJ (2014) Environmental impacts of demersal otter trawls targeting queen scallops (Aequipecten opercularis) in the Isle of Man territorial sea. Fisheries \& Conservation Report No. 35, Bangor University, Bangor

Duffy JE (2003) Biodiversity loss, trophic skew and ecosystem functioning. Ecol Lett 6:680-687

Duplisea DE, Jennings S, Malcolm SJ, Parker R, Sivyer DB (2001) Modelling potential impacts of bottom trawl fisheries on soft sediment biogeochemistry in the North Sea. Geochem Trans 14:1-6

Eigaard OR, Bastardie F, Breen M, Dinesen GE, Hintzen NT, Laffargue P, Mortensen LO, Nielsen R, Nilsson HC, O'Neill FG, Polet H, Reid DG, Sala A, Sköld M, Smith C, Sørensen TK, Tully O, Zengin M, Rijnsdorp (2015) Estimating seabed pressure from demersal trawls, seines and dredges based on gear design and dimensions. ICES J Mar Sci 73:i27-i43

Fanjul E, Greia MA, Iribarne O (2007) Effects of the dominant SW Atlantic intertidal burrowing crab Chasmagnathus granulatus on sediment chemistry and nutrient distribution. Mar Ecol Prog Ser 341:177-190

Forster S, Glud RN, Gundersen JK, Huettel M (1999) In situ study of bromide tracer and oxygen flux in coastal sediments. Estuar Coast Shelf Sci 49:813-827

Gilbertson WW, Solan M, Prosser JI (2012) Differential effects of microorganism-invertebrate interactions on benthic nitrogen cycling. FEMS Microbiol Ecol 82:11-22

Godbold JA, Solan M (2009) Relative importance of biodiversity and the abiotic environment in mediating an ecosystem process. Mar Ecol Prog Ser 396:273-282

Hale R, Mavrogordato MN, Tolhurst TJ, Solan M (2014) Characterizations of how species mediate ecosystem properties require more comprehensive functional effect descriptors. Sci Rep 4:6463

Hale R, Wood CL, Godbold JA, Solan M (2017) Quantification of macrofaunal activity in the Irish Sea. British Oceanographic Data Centre-Natural Environment Research Council, UK. doi:10.5285/475520d5-bad9-4d84-e053-6c86abc0b01b

Halpern BS, Walbridge S, Selkoe KA, Kappel CV, Micheli F, D'Agrosa CD, Bruno JF, Casey KS, Ebert C, Fox HE, Fujita R, Heinemann D, Lenihan HS, Madin EMP, Perry MT, Selig ER, Spalding M, Steneck R, Watson R (2008) A global map of human impact on marine ecosystems. Science 319:948-952

Hinz H, Prieto V, Kaiser MJ (2009) Trawl disturbance on benthic communities: chronic effects and experimental predictions. Ecol Appl 19:761-773

Jones JB (1992) Environmental impact of trawling on the seabed: a review. N Z J Mar Freshw Res 26:59-67

Kaiser MJ, Ramsay K, Richardson CA, Spence FE, Brand AR (2000) Chronic fishing disturbance has changed shelf sea benthic community structure. J Anim Ecol 69:494-503

Kaiser MJ, Collie JS, Hall SJ, Jennings S, Poiner IR (2002) Modification of marine habitats by trawling activities: prognosis and solutions. Fish Fish 3:114-136

Kaiser MJ, Clarke KR, Hinz H, Austen MCV, Somerfield PJ, Karakassis I (2006) Global analysis of response and recovery of benthic biota to fishing. Mar Ecol Prog Ser 311:1-14

Kitidis V, Tait K, Woodward EMS, Sivyer D (2017) Seasonal benthic nitrogen cycling in a temperate shelf sea; the Celtic Sea. Biogeochemistry 1-17. doi:10.1007/s10533-0170311-3

Lambert GI, Jennings S, Kaiser MJ, Davies TW, Hiddink JG (2014) Quantifying recovery rates and resilience of seabed habitats impacted by bottom fishing. J Appl Ecol 51:1326-1336

Laverock B, Gilbert JA, Tait K, Osborn AM, Widdicombe S (2011) Bioturbation: impact on the marine nitrogen cycle. Biochem Soc Trans 39:315-320

Levin L, Blair N, DeMaster D, Plaia G, Fornes W, Martin C, Thomas C (1997) Rapid subduction of organic matter by maldanid polychaetes on the North Carolina slope. J Mar Res 55:595-611

Lohrer AM, Thrush SF, Gibbs MM (2004) Bioturbators enhance ecosystem function through complex biogeochemical interactions. Nature 431:1092-1095

Martin J, Puig P, Palanques A, Ribo M (2014) Trawling-induced daily sediment resuspension in the flank of a Mediterranean submarine canyon. Deep Sea Res Part II 104:174-183

Mayer LM, Schick DF, Findlay R, Rice DL (1991) Effects of commercial dragging on sedimentary organic matter. Mar Environ Res 31:249-261

Mayer LM, Macko SA, Cammen L (1998) The provenance, concentration and nature of sedimentary organic nitrogen in the Gulf of Maine. Mar Chem 25:291-304

Mermillod-Blondin F, Rosenberg R, Francois-Carcaillet F, Norling K, Mauclaire L (2004) Influence of bioturbation by three benthic infaunal species on microbial communities and biogeochemical processes in marine sediment. Aquat Microb Ecol 36:271-284

Middleburg JJ, Levin LA (2009) Coastal hypoxia and sediment biogeochemistry. Biogeoscience 6:1273-1293

Muller-Karger FE, Varela R, Thunell R, Luerssen R, Hu C, Walsh JJ (2005) The importance of continental margins in the global carbon cycle. Geophys Res Lett 32:L01602

Murray LG, Hinz H, Kaiser MJ (2010) Predicted impacts of proposed management measures in the Isle of Man's Pecten maximus fishery. Fisheries \& Conservation Report No. 35, Bangor University, UK

Oberle FKJ, Swarzenski PW, Reddy CM, Nelson RK, Baasch B, Hanebuth TJJ (2016) Deciphering the lithological 
consequences of bottom trawling to sedimentary habitats on the shelf. J Mar Syst 159:120-131

O'Neill FG, Summerbell K (2011) The mobilisation of sediment by demersal otter trawls. Mar Pollut Bull 62:1088-1097

O’Neill FG, Summerbell KJ (2016) The hydrodynamic drag and the mobilisation of sediment into the water column of towed fishing gear components. J Mar Syst 164:76-84

Ormerod SJ, Carleton RG (2016) Connecting the shifting currents of aquatic science and policy. Aquat Conserv 26:995-1004

Osinga R, Lewis WE, Wopereis JLM, Vriezen C, van Duyl FC (1995) Effects of the sea urchin Echinocardium cordatum on oxygen uptake and sulfate reduction in experimental benthic systems under increasing organic loading. Ophelia 41:221-236

Palanques A, Guillen J, Puig P (2001) Impact of bottom trawling on water turbidity and muddy sediment of an unfished continental shelf. Limnol Oceanogr 46:1100-1110

Pansu M, Gautheyrou J (2006) Handbook of soil analysis: mineralogical, organic and inorganic methods. Springer, Berlin

Pilskaln CH, Churchill JH, Mayer LM (1998) Resuspension of sediment by bottom trawling in the gulf of Maine and potential geochemical consequences. Conserv Biol 12:1223-1229

Pinheiro JC, Bates DM (2000) Mixed-effects models in S and S-plus. Springer, New York

Pinheiro J, Bates D, DebRoy S, Sarkar D, R Core Team (2016) nlme: linear and nonlinear mixed effects models. R package version 3.1-128. http://CRAN.R-project.org/package= nlme

Pittman J, Armitage D (2016) Governance across the land-sea interface: a systematic review. Environ Sci Policy 64:9-17

Pommer CD, Olesen M, Hansen JLS (2016) Impact and distribution of bottom trawl fishing on mud-bottom communities in the Kattegat. Mar Ecol Prog Ser 548:47-60

Puig P, Canals M, Company JB, Martin J, Amblas D, Lastras G, Palanques A, Calafat AM (2012) Ploughing the deep sea floor. Nature 489:286-289

Pusceddu A, Bianchelli S, Martín J, Puig P, Palanques A, Masque P, Danavaro R (2014) Chronic and intensive bottom trawling impairs deep-sea biodiversity and ecosystem functioning. Proc Natl Acad Sci USA 111:1-6

Queirós AM, Birchenough SNR, Bremner J, Godbold JA, Parker RA, Romero-Ramirez A, Reiss H, Solan M, Somerfield PJ, Van Colen C, Van Hoey G, Widdicombe S (2013) A bioturbation classification of European marine infaunal invertebrates. Ecol Evol 3:3958-3985

R Core Team (2016) R: a language and environment for statistical computing. R Foundation for Statistical Computing, Vienna

Rao AMF, McCarthy MJ, Gardner WS, Jahnke RA (2007) Respiration and denitrification in permeable continental shelf deposits on the South Atlantic Bight: rates of carbon and nitrogen cycling from sediment column experiments. Cont Shelf Res 27:1801-1819

Rao AMF, McCarthy MJ, Gardner WS, Jahnke RA (2008) Respiration and denitrification in permeable continental shelf deposits on the South Atlantic Bight: N2: Ar and isotope pairing measurements in sediment column experiments. Cont Shelf Res 28:602-613

Riemann B, Hoffmann E (1991) Ecological consequences of dredging and bottom trawling in the Limfjord, Denmark. Mar Ecol Prog Ser 69:171-178

Rocha C (2008) Sandy sediments as active biogeochemical reactors: compound cycling in the fast lane. Aquat Microb Ecol 53:119-127

Rysgaard S, Risgaard-Petersen N, Sloth NP, Jensen K, Nielsen LP (1994) Oxygen regulation of nitrification and denitrification in sediments. Limnol Oceanogr 39:1643-1652

Schiffers K, Teal LR, Travis JMJ, Solan M (2011) An open source simulation model for soil and sediment bioturbation. PLoS ONE 6:e28028

Schindelin J, Arganda-Carreras I, Frise E, Kaynig V, Longair M, Pietzsch T, Preibisch S, Rueden C, Saalfeld S, Schmid B, Tinevez JY, White DJ, Hartenstein V, Eliceiri K, Tomancak P, Cardona A (2012) Fiji:an open-source platform for biological-image analysis. Nat Methods 9:676-682

Sciberras M, Parker R, Powell C, Robertson C, Kröger S, Bolam S, Hiddink JG (2016) Impacts of bottom fishing on the sediment infaunal community and biogeochemistry of cohesive and non-cohesive sediments. Limnol Oceanogr 61:2076-2089

Sciberras M, Tait K, Brochain G, Hale R, Hiddink JG, Godbold JA, Solan M (in review) Community mediation on shelfsea benthic nitrogen cycling following bottom trawling and nutrient enrichment. Biogeochemistry

Seitzinger S, Harrison JA, Böhlke JK, Bouwman AF, Lowrance R, Peterson B, Tobias C, Van Drecht G (2006) Denitrification across landscapes and waterscapes: a synethsis. Ecol Appl 16:2064-2090

Solan M, Cardinale BJ, Downing AL, Engelhardt KAM, Ruesink JL, Srivastava DS (2004a) Extinction and ecosystem function in the marine benthos. Science 306:1177-1180

Solan M, Wigham BD, Hudson IR, Kennedy R, Coulon CH, Norling K, Nilsson HC, Rosenberg R (2004b) In situ quantification of bioturbation using time-lapse fluorescent sediment profile imaging (f SPI), luminophore tracers and model simulation. Mar Ecol Prog Ser 271:1-12

Thomsen MS, Garcia C, Bolam SG, Parker R, Godbold JA, Solan M (2017) Consequences of biodiversity loss diverge from expectation due to post-extinction compensatory responses. Sci Rep 7:43695

Thrush SF, Dayton PK (2002) Disturbance to marine benthic habitats by trawling and dredging: implications for marine biodiversity. Annu Rev Ecol Syst 33:449-473

Trimmer M, Petersen J, Sivyer DB, Mills C, Young E, Parker ER (2005) Impact of long-term benthic trawl disturbance on sediment sorting and biogeochemistry in the southern North Sea. Mar Ecol Prog Ser 298:79-94

Van Colen C, Rossi F, Montserrat F, Andersson MGI, Gribsholt B, Herman PMJ, Degraer S, Vincx M, Ysebaert T, Middelburg JJ (2012) Organism-sediment interactions govern post-hypoxia recovery of ecosystem functioning. PLoS ONE 7:e49795

Volkenborn N, Polerecky L, Wethey DS, DeWitt TH, Woodin SA (2012) Hydraulic activities by ghost shrimp Neotrypaea californiensis induce oxic-anoxic oscillations in sediments. Mar Ecol Prog Ser 455:141-156 
Warnken KW, Gill GA, Dellapenna TM, Lehman RD, Harper DE, Allison MA (2003) The effects of shrimp trawling on sediment oxygen consumption and the fluxes of trace metals and nutrients from estuarine sediments. Estuar Coast Shelf Sci 57:25-42

West BT, Welch KB, Gatecki AT (2007) Linear mixed models. A practical guide using statistical software. Chapman and Hall, London

Wohlgemuth D, Solan M, Godbold J (2016) Specific arrangements of species dominance are more influential than evenness in maintaining ecosystem properties. Sci Rep 6:39325

Wohlgemuth D, Solan M, Godbold JA (2017) Species contributions to ecosystem processes and function can be population dependent and modified by biotic and abiotic setting. Proc R Soc B 284:20162805

Worm B, Barbier EB, Beaumont N, Duffy JE, Folke C, Halpern BS, Jackson JBC, Lotze HK, Micheli F, Palumbi SR, Sala E, Selkoe KA, Stachowicz JJ, Watson R (2006) Impacts of biodiversity loss on ocean ecosystem services. Science 314:787-790

Wrede A, Dannheim J, Gutow L, Brey T (2017) Who really matters: influence of German Bight key bioturbators on biogeochemical cycling and sediment turnover. J Exp Mar Biol Ecol 488:92-101 